\title{
Osvrt na emocionalni aspekt slušanja glazbe
}

\author{
TiHANA ŠKOJO* \\ • https://doi.org/10.31823/d.29.1.5 • \\ UDK: 371.3:78 • Prethodno priopćenje \\ Primljeno: 18. veljače 2020. • Prihvaćeno: 16. ožujka 2021.
}

Sažetak: Unatoč iznimnom zanimanju za istraživanja emocija u glazbi, tek rijetki glazbeni pedagozi upozoravaju na važnost toga fenomena u nastavi glazbe.

U predstavljenom se radu analiziraju rezultati empirijskoga istraživanja radi utvrdivanja doživljenih emocija na slušanje sljedećih glazbenih primjera: C. Saint-Saëns: Karneval životinja, Finale; I. Stravinski: Posvećenje proljeća, Uvod; J. Williams: Schindlerova lista; F. Livadić: Nokturno u fis molu; I. Malec: Lumina te I. Krajač, K. Metikoš i M. Prohaska: Gubec-Beg, Janino ludilo.

${ }^{*}$ Doc. dr. sc. Tihana Škojo, Akademija za umjetnost i kulturu u Osijeku, Sveučilište Josipa Jurja Strossmayera u Osijeku, Ulica Kralja Petra Svačića 1/F, 31000 Osijek, Hrvatska, tihana.skojo@aukos.hr

Rezultati istraživanja aktualiziraju važnost emocionalnoga odgovora učenika na glazbeno djelo te doprinose nastojanjima pojedinih glazbenih pedagoga da naglase potrebu za cjelovitim primanjem glazbenoga djela koje će uz znanje i razumijevanje uključivati i emocionalnu dimenziju.

Ključne riječi: emocije, slušanje, glazbeno djelo, glazbeni repertoar, glazbeni pedagog, nastava glazbene kulture, učenik.

\section{Uvod}

U radu se pregledom brojnih istraživanja, imanentnih osobitostima pojedinoga znanstvenoga područja u okviru kojega se proučava taj fenomen, daje potreban interdisciplinarni kontekstualni okvir za istraživanje koje će u nastavku uslijediti. Metodološki je istraživanje vođeno istraživačkim osobitostima obrazovnih znanosti (pedagogije i glazbene umjetnosti) s naglaskom kako je svrha iskazanoga primijenjenoga istraživanja da posluži u stjecanju znanja i spoznaja iz glazbene pedagogije i unaprijedi glazbenu nastavnu praksu. 
Pobuđivanje emocija kod slušatelja razvidno je još iz zapisa o utjecajima pojedinih ljestvičnih struktura na mladež iz drevne Grčke. ${ }^{1}$ Veliko zanimanje istraživača za tu temu potvrđuju brojna istraživanja, koja su se intenzivno provodila u posljednjih stotinu godina. ${ }^{2}$ Istraživači različitih struka, dominantno psiholozi, a potom glazbeni pedagozi, muzikolozi, muzikoterapeuti, sociolozi, filozofi, ekonomisti i dr. pokazuju izniman interes za rasvjetljavanje toga važnoga fenomena, vođeni istom čarolijom glazbe da trenutačno kod slušatelja inducira emocije na način da $\gg$ ono što u knjizi zahtjeva nekoliko opisnih rečenica u glazbi često može prenijeti tek jedan akord $\ll^{3}$. Istraživanja u psihologiji koja proučavaju odnos glazbe i emocija te mogućnosti poticanja i reguliranja emocija slušanjem glazbe pružaju bogata saznanja o tom zanimljivom i iznimno složenom fenomenu. ${ }^{4}$

Velik broj istraživanja u pogledu utjecaja glazbe na emocije u posljednje je vrijeme ostvaren radi učinkovitije promidžbe proizvoda koji se nalaze na tržištu. ${ }^{5}$ Istraživači proučavaju vezu između emocija potrošača uzrokovanih glazbom i vjerojatnosti kupnje pojedinoga proizvoda, usredotočujući se posebno na odnos poznavanja glazbenoga djela i intenziteta doživljenih emocija. ${ }^{6}$

S obzirom na glazbeni potencijal da regulira emocije, muzikoterapija - koristeći se metodama improvizacije $\mathrm{e}^{7}$ r receptivne muzičke terapije $\mathrm{e}^{8}$ - dolazi do ostvarenja ciljeva koji se odnose na održavanje ili pojačavanje emocionalnoga i mentalnoga stanja slušatelja. ${ }^{9}$

Glazbeni pedagozi, u skladu s prirodom predmeta kojim se bave, slušanje glazbe i emocionalni odgovor na odslušano djelo sagledavaju različito i na brojne ga na-

${ }^{1}$ J. ANDREIS, Povijest glazbe (1), Zagreb, 1971.

${ }^{2}$ P. N. JUSLIN, P. LAUKKA, Expression, perception, and induction of musical emotions. A review and a questionnaire study of everyday listening, u: Journal of New Music Research 33(2004.)3, 217-238.

${ }^{3}$ C. ROBAZZA, C. MACALUSO, V. D'URSO, Emotional reactions to music by gender, age, and expertise, u: Perceptual and motor skills 79(1994.)2, 939-944.

${ }^{4}$ P. N. JUSLIN, D. VÄSTFJÄLL, Emotional responses to music. The need to consider underlying mechanisms, u: Behavioral and brain sciences 31(2008.)5, 559-621.

${ }^{5}$ H. H. PARK, J. K. PARK, J. O. JEON, Attributes of background music and consumers' responses to TV commercials, u: International Journal of Advertising 33(2014.)4, 767-784.

${ }^{6}$ M. I. ALPERT, J. I. ALPERT, E. N. MALTZ, Purchase occasion influence on the role of music in advertising, u: Journal of Business Research 58(2005.)3, 369-376.

${ }^{7}$ K. BRUSCIA, Improvisational models of music therapy, Springfield, 1987.

${ }^{8}$ M. THAUT, B. WHEELER, Music therapy, u: P. JUSLIN, J. SLOBODA (ur.), Music and emotion: Theory, research, applications, Oxford, 2010., 819-848.

9 T. STEGEMANN, M. GERETSEGGER, Music therapy methods, u: B. THOMPSON, J. G. GOLSON (ur.), Music in the social and behavioral sciences, Thousand Oaks, 2014., 768-771. 
čine klasificiraju. ${ }^{10}$ Osjetilno i senzomotoričko slušanje, koje rezultira odgovorom radosti i ushita, strahom, iznenađenjem i drugim emocijama (pozitivnom ili negativnom valencijom) kod slušatelja, čini prvu razinu reagiranja na glazbu. ${ }^{11}$ Emocionalni glazbeni dojam, induciranje emocija kod slušatelja, sljedeći je važan korak $\mathrm{u}$ odgovoru slušatelja na strukturne elemente glazbenoga djela ili djela u cijelosti. Estetske emocije ${ }^{12}$, koje slušatelj manifestira pri slušanju, a odnose se na emocionalne reakcije kao što su osjećaj užitka, nostalgije i sl., važan su početni impuls u zanimanju za glazbeno djelo. Upravo zbog toga pojedini glazbeni pedagozi uočavaju potrebu za revidiranjem spoznajnoga pristupa poučavanju glazbenoga djela, temeljnoga načina približavanja i obrade umjetničke glazbe u školama i upozoravaju na nužnost osvještavanja važnosti emocionalnoga doživljavanja u aktivnosti slušanja glazbe na nastavi. ${ }^{13}$ Autori iniciraju emocionalni prijam i doživljaj glazbenoga djela te ističu praktičnu mogućnost implementacije emocija u aktivnost slušanja kroz tri pristupa - senzomotorički, osjetilni i imaginativni. ${ }^{14} \mathrm{Uz}$ navedeno ističu kako je s glazbeno-pedagoškoga aspekta potrebno promišljati i o utjecaju glazbenoga obrazovanja na emocije te zaključuju kako se percepcije slušatelja o odslušanoj glazbi i emocionalni okidači u pojedinom djelu mijenjaju u skladu sa slušateljevim poznavanjem glazbe. ${ }^{15}$

\section{Aktivnost slušanja u glazbenoj nastavi i utjecaj na doživljene emocije}

Zadatak je glazbenih pedagoga pri aktivnosti slušanja prvotni emocionalni doživljaj, utemeljen na odgovarajućoj pobuđenosti, raspoloženju, emociji, pomoću adekvatnih metodičkih postupaka i glazbene analize dovesti do glazbeno-estetskoga iskustva. U tome procesu nastavnik ima ulogu posrednika između glazbe i učenika, a ona je presudna. Prvi je korak, svakako, odabiranje lijepe i atraktivne glazbe, one za koju pretpostavljamo da će ju učenici uz odgovarajuću metodičku obradu bez poteškoća prihvatiti te koja je, u tehničkom pogledu i u pogledu izvedbe glazbe,

${ }^{10}$ P. ROJKO, Metodika nastave glazbe. Teorijsko tematski aspekti, Osijek, 2012.

${ }^{11}$ K. MADDEN, Aesthetic Response, u: W. F. THOMPSON (ur.), Music in the social and behavioral sciences, Thousand Oaks, 2014., 22-25.

${ }^{12}$ E. BRATTICO, B. BOGERT, T. JACOBSEN, Toward a neural chronometry for the aestetic experience of music, u: Frontiers in Psychology 4(2013.), 1-21.

${ }^{13}$ S. VIDULIN, D. RADICA, Spoznajno-emocionalni pristup slušanju glazbe u školi: teorijsko polazište, u: S. VIDULIN (ur.), Glazbena pedagogija u svjetlu sadašnjih i budućih promjena 5, Pula, 2017., $55-71$.

${ }^{14}$ S. VIDULIN, Strategies for Listening to Music and Music Appreciation in Compulsory School, u: The Journal of Music Education 31(2019.), 57-68.

${ }^{15} \mathrm{~T}$. ŠKOJO, Induciranje emocija glazbom s osvrtom na ulogu glazbene poduke, u: Nova prisutnost 18(2020.)1, 101-114. 
najbolje moguće kvalitete i estetske vrijednosti. ${ }^{16}$ Slušanju glazbe uvijek treba pristupiti predradnjama kojima se učenici pripravljaju na tu aktivnost. Zadavanjem zadataka, koji ovise o uzrastu i glazbenome iskustvu učenika, a odnose se na opažanje izvođača, tempa, dinamike, ugođaja i karaktera, praćenje teme i njezinih preobrazbi, opažanja glazbenih oblika, vrsta i dr., učenike će se podučiti aktivnom slušanju djela. Dobro osmišljenim zadatcima, koji se zadaju prije slušanja, te njihovom izmjenom motivirat će se učenike za višekratno slušanje i omogućiti percepcija glazbenoga djela iz različitih perspektiva. Nakon priprave za slušanje učenici će uz nastavnikovu podršku, iskazanu neverbalnom komunikacijom (pokretima i izrazima lica), pratiti glazbu, spoznavati i razumijevati glazbeno djelo. U razgovoru, koji će potom uslijediti, učenici će doći do kognitivnoga ishoda slušanja, osvijestit će i verbalizirati ono što su čuli i slušno opazili. Također će se odmoriti između dvaju slušanja te se ponovno pripremiti za novo slušanje. ${ }^{17}$

Sažeto iskazano, prvotne afektivne reakcije učenika na glazbeno djelo višekratnim slušanjem i upoznavanjem glazbenoga djela te evaluacijskim procesima procjene ljepote i kvalitete djela dovest će do glazbeno-estetskoga doživljaja i oblikovanja glazbene preferencije, kao ciljne kategorije pedagoški usmjerenoga aktivnoga slušanja glazbe. Estetski doživljaj djela, kao konačni dio procesa slušanja, osim prosudbe i uvažavanja glazbenoga djela te utvrđivanja pojedinoga stupnja glazbene preferencije, u konačnici će ponovno rezultirati doživljenim emocijama kod učenika. ${ }^{18}$

Zainteresiranost za emocionalni odgovor učenika na odslušanu glazbu kod glazbenih pedagoga razvidna je i s aspekta promišljanja o prikladnom slušnom repertoaru. U istraživanjima procjene emocija u glazbenim djelima koja ispitanicima nisu bila poznata utvrđeno je kako se već nakon prvoga slušanja djela uspostavlja emocionalna shema koja se u svojem temeljnom obliku prenosi u dugoročnu memoriju, tako da se pri ponovnom slušanju istoga djela ista shema ponovno aktivira, uz dodavanje dodatnih uočenih podataka o djelu. ${ }^{19} \mathrm{U}$ skladu s tim učenici već nakon prvoga slušanja, a na temelju pojedinih akustičkih značajki, mogu prepoznati osnovne emocije sreće, tuge i ljutnje. ${ }^{20}$ Brojna istraživanja također ističu dominantnu povezanost elemenata glazbene izražajnosti na doživljene emocije. ${ }^{21}$ Povezanost između

${ }^{16}$ P. ROJKO, Metodika glazbene nastave - praksa II. dio: Slušanje glazbe, Zagreb, 2005.

${ }^{17}$ Isto.

${ }^{18}$ H. LEDER, B. BELKE, A. OEBERST, D. AUGUSTIN, A model of aesthetic appreciation and aesthetic judgements, u: British journal of psychology 95(2004.), 489-508.

${ }^{19}$ I. DELIÈGE, Similarity relations in listening to music: How do they come into play?, u: Musicae Scientiae 4(2007.), 9-37.

${ }^{20}$ M. A. CASTELLANO, J. J. BHARUCHA, C. L. KRUMHANSL, Tonal hierarchies in the music of North India, u: Journal of Experimental Psychology 113(1984.), 394-412.

${ }^{21}$ P. N. JUSLIN, J. A. SLOBODA, Music and emotion: Theory and research, New York, 2001. 
doživljenih emocija i različitih glazbenih stilova i žanrova upućuje na dominaciju elementa tempa i ritma u predstavljenom djelu i induciranja pojedine emocije kod slušatelja. ${ }^{22}$ Recentno istraživanje upućuje, osim na utjecaj melodijsko-ritamske i strukturne građe odabranih glazbenih djela na doživljavanje emocija kod učenika, i na izvanglazbene konotacije glazbe te kontekstualni utjecaj. Autorice istraživanja ističu kako je »objašnjavanjem konteksta kroz uvodnu priču i druge neglazbene aktivnosti moguće neke elemente koje glazba donosi naglasiti ili reducirati $\ll^{23}$. Provedeno je istraživanje koje je obuhvaćalo obrade skladbi Maskarada, Valcer, A. Hačaturijana; Wellingtonova pobjeda L. van Beethovena; Šeherezada, More i Sindbadov brod N. Rimski-Korsakova i Pavana G. Faurèa spoznajnim pristupom ${ }^{24}$ i spoznajnoemocionalnim pristupom. ${ }^{25}$ Aktivnost slušanja u spoznajno-emocionalnom pristupu bila je oplemenjena i drugim asocijativnim elementima vezanim uz svako djelo te izvanglazbenim popratnim sadržajima, poput priče, ali i ostalim aktivnostima kao što su izrađivanje maske, gluma, ples i dr. Nakon provedenoga eksperimenta ispitanici su procjenjivali, među ostalim, u kojoj je mjeri svaka od skladbi izazivala sljedeće emocije: veselje, ljutnju, mržnju, gađenje, uznemirenost, iznenađenje, nadu, tugu, strah i oduševljenje. Zaključeno je da su ispitanici koji su ta glazbena djela obrađivali spoznajno-emocionalnim pristupom osjećali »nešto više veselja, iznenađenja i nade $\ll$ u pojedinim skladbama te $\gg$ manje ljutnje, mržnje i tuge $\ll^{26}$.

U istraživanjima emocionalnih odgovora na atonalnu glazbu zaključuje se kako je sudionicima teže prepoznati glazbenu strukturu $\mathrm{u}$ atonalnim djelima od onih $\mathrm{u}$ tonalnim te su i inducirane emocije slabijega intenziteta. ${ }^{27}$ Također su za glazbene pedagoge značajni rezultati istraživanja emocija i atonalne glazbe koji upućuju na velike individualne razlike $u$ odgovorima slušatelja s obzirom na akademsko glazbeno obrazovanje i veće iskustvo $s$ atonalnom glazbom. ${ }^{28}$

${ }^{22}$ F. DILLMAN-CARPENTIER, R. F. POTTER, Effects of music on physiological arousal: Explanations into tempo and genre, $\mathrm{u}$ : Media Psychology 10(2007.)3, 339-363.

${ }^{23}$ S. VIDULIN, M. PLAVŠIĆ, V. ŽAUHAR, Usporedba spoznajnog i emocionalnog aspekta slušanja glazbe u glazbeno-pedagoškom kontekstu osnovne škole, u: Metodički ogledi: časopis za filozofiju odgoja 26(2019.)2, 9-32., ovdje 27.

${ }^{24}$ Isto. P. ROJKO, Metodika glazbene nastave - praksa II. dio: Slušanje glazbe.

${ }^{25}$ Isto. S. VIDULIN, D. RADICA, Spoznajno-emocionalni pristup slušanju glazbe u školi: teorijsko polazište, $55-71$.

${ }^{26}$ Isto. S. VIDULIN, M. PLAVŠIĆ, V. ŽAUHAR, Usporedba spoznajnog i emocionalnog aspekta slušanja glazbe u glazbeno-pedagoškom kontekstu osnovne škole, 9-32., 27.

${ }^{27} \mathrm{H}$. DAYNES, Listeners' perceptual and emotional responses to tonal and atonal music, u: Psychology of Music 39(2010.)4, 468-502.

${ }^{28}$ C. L. KRUMHANSL, G. J. SANDELL, D. G. SERGEANT, The perception of tone hierarchies and mirror forms in twelve-tone serial music, u: Music Perception 5(1987.)1, 31-78. 
U posljednje su se vrijeme intenzivirala istraživanja emocionalnih učinaka vokalno-instrumentalne glazbe s posebnim naglaskom na tekstualni element u glazbi. Rezultati su potvrdili važnost tekstova pri određivanju afektivnoga utjecaja glazbe, ali i fleksibilnost koja je razvidna pri promjeni afektivne valencije djela. Iz istraživanja je razvidno kako su tužni tekstovi doveli do negativnih pomaka u emocijama slušatelja, bez obzira na to jesu li bili upareni s brzom ili polaganom melodijom. ${ }^{29}$ Zanimljivo je istaknuti kako, iako su istraživanja emocija u glazbi bila dominantno usmjerena na induciranje emocija u glazbi zapadnoga tonskoga sustava i zapadne glazbene tradicije, ona malobrojna istraživanja koja se odnose na interkulturnu sposobnost slušatelja da prepozna emociju u glazbi druge kulture upućuju na postojanje određenoga stupnja univerzalnosti za pojedine osnovne emocije. ${ }^{30}$

Iz navedenoga je razvidna važna i zahtjevna uloga nastavnika glazbe, a odnosi se na zadaću da svojim učenicima, uz sve glazbene ljepote i vrijednosti, otkriju i osvijeste emocije u glazbi najrazličitijega glazbenoga repertoara.

\section{Metodologija pedagoškoga istraživanja}

\section{CiLJ, PROBLEMI I HIPOTEZE ISTRAŽIVANJA}

Istraživanje je provedeno radi ispitivanja doživljenih emocija na slušanje glazbe. Istaknuti cilj u skladu je s psihološkim načelom kurikula predmeta Glazbena kultura / Glazbena umjetnost ${ }^{31}$, na kojemu se temelji učenje i poučavanje predmeta, a koji ističe da učenici emotivno reagiraju na glazbu i na taj način učvršćuju vlastiti odnos s glazbom.

U skladu s oblikovanim ciljem postavljeni su sljedeći problemi istraživanja:

1. Ispitati utjecaj dobi na doživljene emocije.

2. Ispitati utjecaj spola na doživljene emocije.

3. Ispitati utjecaj poznavanja glazbenoga djela na doživljene emocije.

\footnotetext{
${ }^{29}$ V. N. STRATTON, A. H. ZALANOWSKI, Affective impact of music vs. Lyrics, u: Empirical studies of the arts 12(1994.), 173-184.; S. D. SOUSOU, Effects of melody and lyrics on mood and memory, u: Perceptual and Motor Skills 85(1997.)1, 31-40.

${ }^{30}$ L. BALKWILL, W. F. THOMPSON, A cross-cultural investigation of the perception of emotion in music: psychophysical and cultural cues, u: Music Perception 17(1999.)1, 43-64.

${ }^{31}$ MINISTARSTVO ZNANOSTI I OBRAZOVANJA, Odluka o donošenju kurikula za nastavni predmet Glazbene kulture za osnovne škole i Glazbene umjetnosti za gimnazije u Republici Hrvatskoj, Zagreb, 2019.
} 


\section{SUDIONICI, INSTRUMENT I POSTUPAK ISPITIVANJA}

Ispitivanje je provedeno na uzorku od 302 učenika $(\check{Z}=181 ; M=121)$ šestoga $i$ osmoga razreda osnovne škole te drugoga i četvrtoga razreda gimnazije iz Osječkobaranjske županije.

Za potrebe je istraživanja autorica oblikovala upitnik sastavljen od dvaju dijelova - u prvome dijelu nalaze se pitanja koja se odnose na obilježja učenika (dob, spol, škola i razred), dok se drugi dio upitnika odnosi na procjenu jačine doživljene emocije i poznavanje glazbenoga djela. Odabir emocija uključenih u upitnik ostvaren je po uzoru na emocije uključene u računalni program Sat emocionalnih smajlića (engl. The emotion-face clock interface ${ }^{32}$ ). Emocije su temeljene na osnovnih šest emocija (sreća, tuga, ljutnja, strah, iznenađenje i gađenje), ali je, prema kriterijima u radu Schuberta i suradnika, iznenađenje zamijenjeno uzbuđenjem, gađenje je izbačeno, a umjesto njega dodana je smirenost. U skladu s tim ljutnja je dodatno proširena tako da joj je dodana uznemirenost, kao suprotnost smirenosti. ${ }^{33}$ Zadatak učenika jest da, nakon što su odslušali glazbeni ulomak, prvo odaberu jednu od šest navedenih emocija koju su doživjeli slušajući. Potom su na skali odgovora od pet stupnjeva (od $1=$ nimalo do 5 = izuzetno jako) trebali procijeniti jačinu doživljene odabrane emocije. Nakon toga su trebali iskazati je li im skladba poznata ili nepoznata $(1=$ poznato $\mathrm{mi} \mathrm{je} ; 2$ = nepoznato $\mathrm{mi} \mathrm{je})$.

U istraživanju je korišten nosač zvuka, oblikovan za potrebe istraživanja, sa 6 glazbenih ulomaka (Tablica 1). Svaki je glazbeni ulomak prezentiran najznačajnijim i najefektnijim dijelom, u trajanju od 1,5 do 2 minute. Ulomci su se nizali iskazanim redoslijedom, s najavljivanjem rednoga broja pojedinoga primjera, bez isticanja naziva djela, autora ili drugih objašnjenja kako ne bismo utjecali na iskrenost u odgovoru ni eventualnim asocijacijama na izvanglazbeni sadržaj sugerirali određenu emociju. ${ }^{34}$

Glazbeni su primjeri europske glazbe odabrani na temelju iskustava ${ }^{35} \mathrm{u}$ recentnim istraživanjima o glazbi i emocijama. Autori su u navedenim istraživanjima, ovisno

${ }^{32}$ E. SCHUBERT, S. FERGUSON, N. FARRAR, D. TAYLOR, G. E. MCPHERSON, The Six Emotion - Face Clock as a Tool for Continouosly Rating Discrete Emotional Responses to Music, u: M. ARAMAKI, M. BARTHET, R. KRONLAND-MARTINET, S. YSTAD (ur.), From Sounds to Music and Emotions, Revised Selected Papers $9^{\text {th }}$ International Symposium, London, 2012., 1-19.

${ }^{33}$ G. KREUTZ, U. OTT, D. TEICHMANN, P. OSAWA, D. VAITL, Using to induce emotions: Influences of musical preference and absorption, u: Pedagogy of Music 36(2008.) 1, 101-126.

${ }^{34}$ P. ROJKO, Metodika nastave glazbe. Teorijsko-tematski aspekti, Osijek, 1996.

${ }^{35}$ K. KALLINEN, N. RAVAJA, Emotion perceived and emotion felt. Same or different, u: Musicae Scientiae, 10(2006.)2, 191-213.; A. OMAR, Z. PEYNIRCIOĞLU, Songs and emotions. Are lyrics and melodies equal partners?, u: Psychology of Music 34(2006.)4, 511-534.; H. DAYNES, Listeners' perceptual and emotional responses to tonal and atonal music, u: Psychology of Music 39(2010.) 4, 468-502. 
o osobnim procjenama emocionalnoga sadržaja djela i utvrđenom cilju istraživanja, odabirali glazbene ulomke različitih žanrova, instrumentalne i vokalno-instrumentalne glazbe i prezentirali ih ispitanicima u trajanju od najmanje 20 sekundi. Ispitanici su potom odabiranjem jedne od navedenih emocija iskazivali doživljenu emociju. Po istom je uzoru 2019. godine ostvareno i prvo istraživanje u kojemu su uz strane glazbene primjere korišteni i primjeri iz hrvatske umjetničke baštine. ${ }^{36}$ $\mathrm{U}$ istraživanju su od primjera hrvatske glazbe korišteni isključivo instrumentalni ulomci, koji su u ovom istraživanju prošireni s vokalno-instrumentalnim (scenskim) glazbenim djelom.

Tablica 1. Slušni primjeri

\begin{tabular}{|l|}
\hline Naziv primjera \\
\hline Camille Saint-Saëns: Karneval životinja, Finale \\
\hline Igor Stravinski: Posvećenje proljeća, Uvod \\
\hline John Williams: Schindlerova lista \\
\hline Ferdo Livadić: Nokturno u fis-molu \\
\hline Ivo Malec: Lumina \\
\hline Ivica Krajač, Karlo Metikoš, Miljenko Prohaska: Gubec-beg, Janino ludilo \\
\hline
\end{tabular}

\section{Rezultati istraživanja i interpretacija}

\section{Primjer br. 1. Camille Saint-Saëns: Karneval životinja, Finale}

Taj je ulomak kod $53 \%$ učenika izazvao emociju sreće, kod $26 \%$ njih izazvao je uzbuđenje, kod 12,6 \% učenika smirenost, kod 4,6 \% učenika strah, a 3,9 \% učenika bilo je ljutito, uznemireno pri slušanju toga ulomka, dok je troje učenika (1\%) izjavilo da je osjetilo tugu pri slušanju toga djela. Za taj je ulomak 146 učenika, tj. polovica sudionika navela da im je poznat.

Hi-kvadrat kojim se provjeravalo postoje li dobne razlike u doživljenim emocijama nije značajan $\left(\chi^{2}=24,51 ; p=0,057\right)$. Kako je značajnost toga testa relativno blizu graničnoj uz manju razinu sigurnosti, a jedan se odnos opaženih i teorijskih frekvencija ističe, taj ćemo odnos i spomenuti: $11 \%(\mathrm{f}=34)$ učenika četvrtih razreda srednje škole navelo je da im taj ulomak izaziva uzbuđenje, što je dosta više od broja učenika koji odgovara teorijskim frekvencijama. Iako se ne može reći da su se emocionalne reakcije na to djelo različitom frekvencijom pojavljivale kod učenika različite dobi, ipak treba dodati malu ogradu za uzbuđenje koje se kod najstarijih učenika pojavilo nešto češće nego što bi bilo očekivano. Pretpostavljamo da je izraženija

\footnotetext{
${ }^{36}$ Isto. T. ŠKOJO, Induciranje emocija glazbom s osvrtom na ulogu glazbene poduke, 101-114.
} 
emocionalna reakcija na to djelo, koja je razvidna kod najstarijih učenika, proizišla iz interakcije različitih glazbenih karakteristika, odnosno zbog izrazite specifičnosti glazbenoga ulomka. Specifična akustička obilježja toga djela, koja se odnose na brzi, razigrani tempo i postupno ubrzavanje (accelerando) uzrokovala su pobuđivanje jednoga od mehanizama koji se aktiviraju pri emocionalnom doživljaju glazbe i uzrokovala su emocionalnu zarazu i usklađivanje s ritmom djela ${ }^{37}$ te na taj način uzbuđenje. Na novi teorijski okvir koji sadrži šest dodatnih mehanizama, koji se po potrebi aktiviraju pri slušanju glazbe ovisno o karakteristikama djela, upozoravaju u istraživanju Juslin i Västfjäll te opsežno pojašnjavaju sintezom teorija iz različitih znanstvenih područja.

Za dvije emocije koje su sudionici najčešće navodili (sreća i uzbuđenje) pri slušanju toga primjera provjereno je jednosmjernom analizom varijance postoji li statistički značajna razlika $u$ intenzitetu tih emocija kod učenika različite dobi te su analize pokazale da ne postoji takva razlika. Za obje je emocije intenzitet na osrednjoj razini - pri tome je prosječna vrijednost za sreću 3,37 $(\mathrm{SD}=0,937)$, a za uzbuđenje $3,07$ ( $S D=0,848)$. Uzorak se razdijelio na one kojima je ulomak poznat i na one kojima je nepoznat - provjerilo se hi-kvadratom postoje li dobne razlike u tome kome je poznat i utvrđeno je da takve razlike ne postoje, odnosno u jednakom je omjeru poznat učenicima različite dobi. Budući da se djelo nalazi u nastavnom programu za drugi razred osnovne škole ${ }^{38}$, smatramo da je metodički kvalitetna realizacija aktivnosti slušanja razlogom poznavanja glazbenoga ulomka.

Provjereno je hi-kvadratom i razlikuje li se frekvencija učenika koji navode da su doživjeli neku od šest ponuđenih emocija s obzirom na njihov spol i poznatost djela. Djevojčice i dječaci nisu se razlikovali po učestalosti doživljavanja šest spomenutih emocija. Provjerilo se i doživljavaju li učenici kojima je ulomak poznat i oni kojima je nepoznat emocionalne reakcije jednakom čestinom - tu postoje razlike $\left(\chi^{2}=13,71 ; p=0,018\right)$ te je uvid u opažene i teorijske frekvencije pokazao da oni kojima je ulomak poznat u većem broju nego što bi bilo očekivano navode da su doživjeli sreću i smirenost, dok oni kojima je ulomak nepoznat to navode u manjem broju nego što bismo teorijski očekivali. Dakle poznatost djela dovela je do toga da učenici dožive sreću ili smirenost slušajući to djelo. Rezultat potvrđuje zaključak istraživanja u kojem se navodi kako se većim poznavanjem pojedinoga glazbenoga djela povećao intenzitet pozitivnih emocija kod slušatelja. ${ }^{39}$

\footnotetext{
${ }^{37}$ Isto. P. N. JUSLIN, D. VÄSTFJÄLL, Emotional responses to music, 559-621.

${ }^{38}$ MINISTARSTVO ZNANOSTI, OBRAZOVANJA I ŠPORTA, Nastavni plan i program za osnovnu školu, Zagreb, 2006.

${ }^{39}$ K. KALLINEN, N. RAVAJA, Emotion perceived and emotion felt, 191-213.
} 
Provjerene su razlike $\mathrm{u}$ intenzitetu doživljene emocije ( $\mathrm{t}$-testom za nezavisne uzorke) s obzirom na spol sudionika i poznatost ulomka. Učenice $(\mathrm{M}=3,29 ; \mathrm{SD}=$ $0,916)$ su intenzivnije doživjele $\left(t_{302}=2,08 ; p=0,038\right)$ ulomak nego učenici $(M$ $=3,06$; $\mathrm{SD}=0,994)$ - razlika je značajna uz razinu rizika od $5 \%$ pa je u skladu s tim, iako učenice statistički imaju intenzivnije emocije, u stvarnosti razlika u doživljenom intenzitetu emocija vrlo mala - na ljestvici odgovora od 1 do 5 razlika između učenika i učenica ne iznosi ni četvrtinu $(0,23)$ jedne jedinice intenziteta. Razlikuju se $\left(\mathrm{t}_{302}=-4,44 ; \mathrm{p}=0,000\right)$ i intenziteti doživljenih emocija kod učenika koji poznaju $(M=3,45 ; S D=0,895)$ i koji ne poznaju djelo $(M=2,99 ; S D=0,948)$ - intenzivniju emociju doživljavaju oni kojima je djelo poznato i ona je na granici između osrednjega i dosta jakoga intenziteta, dok oni kojima je djelo nepoznato doživljavaju osrednje intenzivnu emociju.

Dakle pri tom ulomku može se uočiti da nešto više od polovice učenika doživljava sreću pri slušanju djela, dok četvrtina učenika doživljava uzbuđenje. Dobne razlike nisu značajne ni u frekvenciji odabranih emocija, ni u njihovu intenzitetu, ni u poznatosti samoga djela. Ipak, uočava se da su najstariji učenici nešto skloniji izvijestiti o doživljaju uzbuđenja, što je vjerojatno povezano i s njihovim kognitivnim razvojem (apstraktnim mišljenjem) i boljim diferenciranjem doživljenih emocija u usporedbi s mlađima.

Gotovo polovica učenika procjenjuje djelo poznatim. Učinci poznatosti odrazili su se na čestinu doživljavanja pojedine emocije u smislu da su oni kojima je djelo poznato u većem broju govorili da im izaziva sreću ili smirenost. Ta pojava, osim prethodno objašnjene obrade navedenoga ulomka, može upućivati i na efekt samoga izlaganja, odnosno pojavu da već jednostavno izlaganje nekom podražaju dovodi do veće preferencije toga podražaja, u ovom slučaju glazbenoga ulomka. Unatoč utvrđenim statističkim razlikama između djevojčica i dječaka, sama veličina razlike toliko je mala da se može smatrati irelevantnom u interpretacijskom ili implementacijskom smislu.

\section{Primjer br. 2. Igor Stravinski: Posvećenje proljeća, Uvod}

Pri tom se ulomku može uočiti da su tri emocije bile podjednako zastupljene u uzorku - $31 \%$ učenika uplašilo se, $30 \%$ bilo je smireno, a $27 \%$ osjetilo je tugu. Ljutito, uznemireno bilo je $8 \%$ učenika, $2 \%$ učenika bilo je sretno, a $2 \%$ uzbuđeno dok je slušalo to djelo. Za taj je ulomak $23 \%$ učenika navelo da im je poznat.

Provjera hi-kvadratom pokazala je da se učenici različite dobi razlikuju po čestini emocija koje navode kao reakciju na taj ulomak $\left(\chi^{2}=38,09 ; \mathrm{p}=0,001\right)$. Usporedba dobivenih i očekivanih frekvencija pokazuje jasne dobne trendove za reakciju straha: više se srednjoškolaca uplašilo nego što je očekivano (u drugome razredu njih 
$12 \%(\mathrm{f}=37)$, dok je očekivano $\mathrm{ft}=30,6$, a u četvrtome njih $\mathrm{f}=36$, dok je očekivano $\mathrm{ft}=30,3)$, dok je kod osnovnoškolaca broj onih koji su reagirali strahom na tu skladbu manji od očekivanoga ( $\mathrm{u}$ šestome razredu njih $\mathrm{f}=14 \mathrm{u}$ odnosu na $\mathrm{ft}=8,3$ očekivanih i u osmome njih $\mathrm{f}=12 \mathrm{u}$ odnosu na $\mathrm{ft}=19,9$ očekivanih). Dakle stariji su učenici više izvještavali o strahu nego mlađi učenici. Po učestalosti doživljene tuge razlikuju se najmlađi i najstariji učenici: $f=23$ učenika šestoga razreda bilo je tužno (očekivalo se $\mathrm{ft}=15,7$ učenika), dok je $\mathrm{f}=17$ učenika četvrtoga razreda ( $\mathrm{u}$ odnosu na očekivanih $\mathrm{ft}=15,7$ ) reklo da im taj ulomak izaziva tugu. Najstariji se učenici po smirenosti razlikuju od učenika osmoga razreda: $u$ četvrtome srednje $\mathrm{f}=24$ je učenika to doživjelo iako je bilo statistički očekivano da to doživi $\mathrm{ft}=$ 29 učenika, dok je u osmome razredu obratno - smireno je bilo $f=25$ učenika, a očekivalo se da će biti $\mathrm{ft}=19,1$. U četvrtome razredu srednje škole ističe se još jedna razlika opaženih $i$ teorijskih frekvencija $-\mathrm{f}=15$ je učenika navelo da se osjeća ljutito, uznemireno, dok je bilo očekivano da će to navesti $\mathrm{ft}=7,6$ učenika. Zaključno, stariji učenici više reagiraju emocijama straha i ljutnje u odnosu na statistička očekivanja, dok mlađi više reagiraju tugom ili smirenošću. Razlog vidimo u tematskoj usmjerenosti pri analizi glazbenog djela, koja je prema nastavnom programu za sedmi razred usmjerena prema obradi instrumenta (u ovom slučaju fagota, koji započinje uvodnu temu ulomka), dok je obrada u srednjoj školi usmjerena prema povijesno-muzikološkom aspektu baleta Posvećenje proljeća iz Stravinskijeva ruskoga razdoblja / nacionalnoga stila. Stoga smatramo kako se odabrane emocije kod srednjoškolaca ne odnose na utjecaj apsolutne glazbe na emocije, već su na temelju poznavanja teme baleta, koji prikazuje poganski ritual iz stare Rusije, odabrane emocije usmjerene izvanglazbenim sadržajem djela.

Kako su tri emocije kao najčešće navodili u podjednakim postotcima, za te je emocije (strah, smirenost i tuga) provjereno jednosmjernom analizom varijance postoji li statistički značajna razlika u intenzitetu tih emocija kod učenika različite dobi. Intenzitet straha nije se razlikovao kod $n=99$ učenika $(32,8 \%)$ različite dobi koji su imali tu emocionalnu reakciju na taj ulomak, a u prosjeku je za sve njih bio osrednje izražen $(M=2,95 ; S D=0,930)$. Ne razlikuju se ni učenici različite dobi po intenzitetu doživljene smirenosti, a prosječni intenzitet te emocije nešto je veći od intenziteta emocije straha u prethodnoj skupini $(M=3,16$; $S D=0,940)$, no i dalje je to osrednja razina intenziteta. Nema dobnih razlika ni u intenzitetu doživljene tuge kod 85 učenika koji su doživjeli tu emociju, a intenzitet njihove emocije najmanji je od triju navedenih emocija, iako je i dalje u kategoriji emocija osrednjega intenziteta $(M=2,85 ; S D=1,086)$. Za taj ulomak tek nešto više od petine učenika navodi da im je poznat. Analiza $\left(\chi^{2}=11,68 ; p=0,009\right)$ je pokazala da postoje dobne razlike: učenici osmoga razreda i četvrtoga razreda srednje škole navode da im je taj ulomak poznat, što je u potpunosti očekivano jer se navedeni ulomak nalazi u 
nastavnom programu predmeta Glazbena kultura sedmoga razreda osnovne škole, kao i u nastavnom programu predmeta Glazbena umjetnost četvrtoga razreda.

Provjerene su učestalosti doživljenih emocija na taj ulomak s obzirom na njihov spol i poznatost djela te su provedeni hi-kvadrati pokazali da ni spol ni poznatost djela ne dovode do razlika u učestalosti doživljenih emocija.

Primjer br. 3. John Williams: Schindlerova lista

Taj je ulomak kod $74 \%$ učenika izazvao tugu, a kod $22 \%$ smirenost, njih 3,5\% doživjelo je strah, troje ( $1 \%)$ uzbuđenje, a jedan učenik sreću $(0,33 \%)$. Za taj je ulomak $38,7 \%$ učenika navelo da im je poznat.

Nisu utvrđene (hi-kvadratom) dobne razlike u učestalosti doživljenih emocija. Provjereno je postoje li dobne razlike u intenzitetu tuge za učenike koji su naveli da je ulomak kod njih izazvao tugu (jednosmjernom analizom varijance). Pokazalo se da postoje dobne razlike $\left(\mathrm{F}_{227,3}=27,59 ; \mathrm{p}=0,000\right)$, a post hoc provjere pokazale su da učenici četvrtoga razreda srednje škole $(M=4,08 ; S D=0,914)$ doživljavaju intenzivniju tugu nego učenici šestoga $(M=3,19 ; S D=1,173)$ i osmoga razreda $(\mathrm{M}=3,32 ; \mathrm{SD}=1,193)$, dok ostale razlike nisu značajne. Dobne razlike u intenzitetu smirenosti nisu utvrđene kod 22,5\% učenika kojima je ulomak izazvao tu reakciju, a prosječna je vrijednost emocije kod tih učenika $\mathrm{M}=3,69 ; \mathrm{SD}=1,123$. Provjerilo se hi-kvadratom razlikuje li se čestina onih koji navode da im je ulomak (ne)poznat s obzirom na to koji razred pohađaju. Taj je hi-kvadrat značajan $\left(\chi^{2}=\right.$ $19,08 ; p=0,000)$, a uvid u odnos opaženih i očekivanih frekvencija upozorava na to da najstariji učenici (četvrti razred srednje škole) više nego što bismo očekivali prepoznaju to djelo, dok mlađi učenici manje nego što bi se statistički očekivalo prepoznaju djelo. Na iskazani je rezultat, smatramo, pridonijela popularnost filma, kao i nagrada Oscar za najbolji film, kojim je uvršten u klasike kinematografije.

Hi-kvadrati su pokazali da se po čestini navođenja pojedinih emocionalnih reakcija ne razlikuju učenice od učenika. Nasuprot tomu, pokazalo se da između tih skupina postoje razlike $u$ intenzitetu doživljenih emocija. Učenice $(M=3,78 ; S D$ $=1,115)$ doživljavaju intenzivnije emocije $\left(\mathrm{t}_{302}=3,37 ; \mathrm{p}=0,001\right)$ nego učenici $(\mathrm{M}$ $=3,34 ; \mathrm{SD}=1,153$ ). Te su razlike, iako statistički značajne, relativno male (razlika aritmetičkih sredina nešto je manja od pola mjerne jedinice na ljestvici odgovora koja ima pet stupnjeva). Ipak, prosječna vrijednost za učenike govori da je emocija na granici osrednje prema dosta intenzivnoj, dok je kod učenica emocija u prosjeku dosta intenzivna. Pokazalo se da oni kojima je ulomak poznat $(M=3,97$; SD $=1,038)$ doživljavaju mnogo intenzivnije emocije $\left(t_{302}=-4,36 ; p=0,000\right)$ od onih kojima je ulomak nepoznat $(\mathrm{M}=3,41$; $\mathrm{SD}=1,160)$. Iako oko $40 \%$ sudionika prepoznaje djelo, ono kod $3 / 4$ njih izaziva jednoznačno emociju tuge, što zorno 
prikazuje da je autor djelom postigao ujednačenost tematike filma i emocije koju slušatelji doživljavaju. U sladu je s tim i podatak da stariji učenici u većoj mjeri nego mlađi izvješćuju o doživljaju tuge, oni vjerojatno i zbog izlaganja filmu u slobodnom vremenu kao i u nastavi, imaju kontekst koji im služi kao osnova za interpretaciju emocionalnih doživljaja. Važnost toga konteksta dodatno podržava i podatak da o intenzivnijim emocijama izvješćuju učenici kojima je djelo poznato.

\section{Primjer br. 4. Ferdo Livadić: Nokturno u fis-molu}

Pri tom je ulomku $49 \%$ učenika doživjelo smirenost te $46 \%$ njih tugu. Šest (2 \%) je učenika navelo da je taj ulomak kod njih izazvao strah, odnosno ljutnju, dok je jedan učenik $(0,33 \%)$ naveo da je ulomak kod njega izazvao uzbuđenje. Za taj je ulomak $28 \%$ učenika navelo da im je poznat.

Dobne razlike u broju onih koji navode da su doživjeli neku od šest ponuđenih emocija pokazale su se statistički značajne uz razinu rizika od $5 \%\left(\chi^{2}=21,98\right.$; $\mathrm{p}=$ $0,038)$, a dobni trendovi upozoravaju na to da veći broj srednjoškolaca od očekivanoga broja doživljava smirenost, a manji broj njih od očekivanoga doživljava tugu, dok je kod osnovaca uočen suprotan trend. Za dvije emocije koje su sudionici najčešće navodili (smirenost i tuga) provjereno je jednosmjernom analizom varijance postoji li statistički značajna razlika u intenzitetu tih emocija kod učenika različite dobi, no za obje su emocije F-omjeri neznačajni, što upućuje na to da dobne razlike $\mathrm{u}$ intenzitetu doživljene tuge i smirenosti ne postoje. Učenici su naveli da je prosječni intenzitet izazvane emocije smirenosti $M=3,63 ; S D=1,160$, što govori da su učenici doživjeli dosta intenzivnu razinu te afektivne reakcije, a u skupini onih kojima je taj ulomak izazvao emociju tuge prosječni je intenzitet izazvane tuge $\mathrm{M}=$ 3,$62 ; \mathrm{SD}=1,208$ - vrlo slična razina intenziteta kao i za smirenost. Pokazalo se da su udjeli učenika kojima je taj ulomak poznat ravnomjerno raspoređeni po različitim razredima, odnosno da nema dobne razlike u poznatosti ulomka $\left(\chi^{2}=1,64 ; \mathrm{p}\right.$ $=0,65$ ).

Provjereno je (hi-kvadratom) razlikuju li se po broju onih koji su doživjeli neku od ponuđenih emocija učenice od učenika i oni kojima je primjer poznat od onih kojima je nepoznat - razlike u obje analize nisu značajne te upućuju na to da ne postoje razlike između tih skupina.

Provjereno je t-testom za nezavisne uzorke razlikuju li se učenice od učenika po intenzitetu doživljene emocije - pokazalo se da učenice $(\mathrm{M}=3,83$; $\mathrm{SD}=1,121)$ doživljavaju intenzivnije emocije $\left(t_{302}=4,42 ; p=0,000\right)$ nego učenici $(M=3,22$; $S D$ $=1,260)$. Emocija je kod učenica dosta, a kod učenika osrednje intenzivna. Učenici kojima je ulomak poznat $(M=4,12 ; S D=1,031)$ doživljavaju mnogo intenzivnije emocije $\left(t_{302}=-4,99 ; \mathrm{p}=0,000\right)$ od onih kojima je ulomak nepoznat $(\mathrm{M}=3,40$; 
$\mathrm{SD}=1,213)$ - ovdje je vidljivo da učenici kojima je ulomak poznat navode da im je izazvao dosta intenzivnu emociju, dok je emocija onih kojima je ulomak nepoznat osrednjega intenziteta i kreće se prema dosta visokom intenzitetu.

Kod toga djela može se uočiti da se uzorak učenika podijelio između dviju doživljenih emocija - tuge koju češće doživljavaju osnovci i smirenosti koju češće doživljavaju srednjoškolci. Tuga, kao primarna emocija, možda je mlađim učenicima, moguće i manje emocionalno pismenima, bila dovoljno dobra aproksimacija doživljenoga. $S$ druge strane očekivano je da su stariji učenici bili izloženiji složenijim analizama samoga djela tijekom obrazovanja. Nadalje se pokazalo da djevojčice i učenici kojima je to djelo poznato izvješćuju o intenzivnijim emocijama nego dječaci i učenici koji ne poznaju djelo - $\mathrm{s}$ obzirom na poznate spolne razlike u prepoznavanju i izražavanju emocija koje pokazuju da dječaci inhibiraju sve emocije, a djevojčice socijalno nepoželjne emocije poput ljutnje ${ }^{40}$, iznenađuje da su utvrđene te razlike. Očito je i poznavanje djela, koje omogućava interpretacijski kontekst, potaknulo i doživljavanje intenzivnijih emocija - opet, moguće je da se oni koji su se ranije susreli s tim djelom koriste iskustvenim informacijama i da one doprinose i intenzitetu doživljene emocije. Poznatost djela, pokazalo se, omogućuje predviđanje i razvijanje očekivanja, a što doprinosi i emocionalnom doživljaju ${ }^{41}$. Ipak, pokazalo se da će učinci poznatosti na intenzitet emocija biti izraženiji kod višestrukoga i čestoga izlaganja ${ }^{42}$ - iako ta informacija nije prikupljana u ovom istraživanju, podatak da je tek $28 \%$ učenika navelo da im je djelo poznato ne govori u prilog pretpostavci da su učenici često izlagani tom djelu.

\section{Primjer br. 5. Ivo Malec: Lumina}

Ulomak Lumina kod $52 \%$ učenika izazvao je ljutnju, a $34 \%$ njih taj je ulomak uplašio, dok je $7 \%$ doživjelo uzbuđenje, $3 \%$ osjetilo je tugu, $2 \%$ smirenost, a $1 \%$ sreću. Za taj je ulomak $16 \%$ učenika navelo da im je poznat.

Za dvije emocije koje su sudionici najčešće navodili (ljutnja i strah) provjereno je jednosmjernim analizama varijance postoji li statistički značajna razlika u intenzitetu tih emocija kod učenika različite dobi te nisu utvrđene statistički značajne dobne razlike ni za ljutnju ni za strah. Provjereno je postoje li dobne razlike u tome komu je ulomak (ne)poznat te je taj hi-kvadrat značajan $\left(\chi^{2}=12,46\right.$; $\left.\mathrm{p}=0,006\right)$, a uvid u

\footnotetext{
${ }^{40}$ L. R. BRODY, Gender differences in emotional development: A review of theories and research, $\mathrm{u}$ : Journal of personality 53(1985.)2, 102-149.

${ }^{41}$ I. VAN DEN BOSCH, V. SALIMPOOR, R. J. ZATORRE, Familiarity mediates the relationship between emotional arousal and pleasure during music listening, $\mathrm{u}$ : Frontiers in human neuroscience 7(2013.), 534

${ }^{42}$ A. OMAR, Z. PEYNIRCIOĞLU, Songs and emotions, 511-534.
} 
odnos opaženih i očekivanih frekvencija upozorava na razlike kod broja učenika 8 . razreda osnovne škole i drugoga razreda srednje škole koji navode da im je ulomak poznat: $\mathrm{f}=18$ učenika osmoga razreda navelo je da im je ulomak poznat, dok bi, po teorijskim vrijednostima, bilo očekivano da će to navesti $\mathrm{ft}=9,8$ učenika, dok je među učenicima drugoga razreda srednje škole osmero $(f=8)$ učenika navelo da im je ulomak poznat, a očekivalo se da će to navesti $\mathrm{ft}=15$ učenika. Dakle učenici pred kraj osnovne škole navode da im je ulomak poznatiji nego što je očekivano, dok početkom srednje škole manji broj učenika od očekivanoga prepoznaje taj ulomak.

Hi-kvadratima je utvrđeno da se učenice ne razlikuju od učenika po tome koje su emocije naveli kao reakciju na slušano djelo, no pokazalo se da se razlikuju učenici koji su naveli da im je ulomak poznat od onih kojima je nepoznat $\left(\chi^{2}=21,97\right.$; $\mathrm{p}=$ $0,001)$. Uvid u frekvencije onih koji su naveli da su imali neku od navedenih emocija u usporedbi s očekivanim frekvencijama, a ovisno o tome je li im ulomak poznat ili nije, upozorava na to da veći broj učenika kojima je ulomak nepoznat (nego što bi to bilo očekivano) navodi da ih je taj ulomak naljutio, a suprotno se opaža kod onih kojima je ulomak poznat; za tugu i uzbuđenje jest obratno: više učenika kojima je taj ulomak poznat, nego što je to statistički očekivano, navodi da ih je ulomak rastužio ili uzbudio (kod onih kojima je ulomak nepoznat, naravno, obratan je trend). Nisu utvrđene spolne razlike u intenzitetu doživljenih emocija, a nema razlika ni u intenzitetu emocija koje su doživjeli učenici kojima je djelo poznato i oni kojima je nepoznato.

Na temelju analiza provedenih uz taj ulomak ističe se njegova nepoznatost - prepoznaje ga tek $16 \%$ učenika, što je u potpunosti očekivano s obzirom na to da se navedeni ulomak ne nalazi u nastavnom programu. Budući da je ulomak zahtjevne glazbene strukture, pretpostavljamo da se ne nalazi ni u odabranom dodatnom repertoaru nastavnika glazbene kulture i umjetnosti.

Primjer br. 6. Ivica Krajač, Karlo Metikoš, Miljenko Prohaska: Gubec-beg, Janino ludilo

Slušajući taj ulomak, $37 \%$ učenika navodi da osjeća tugu, $28 \%$ njih bilo je smireno, $26 \%$ uplašilo se, dok je $8 \%$ bilo ljutito. Sretan je bio $1 \%$ učenika i samo se jedan učenik $(0,33)$ osjećao uzbuđeno pri slušanju toga ulomka. Za taj je ulomak 10,6 \% učenika navelo da im je poznat.

Značajnost hi-kvadrata upozorava na to da postoje dobne razlike u frekvencijama onih koji su doživjeli neku od ponuđenih emocija $\left(\chi^{2}=31,78\right.$; $\left.p=0,007\right)$. Najuočljiviji su dobni trendovi kod učenika koji su doživjeli smirenost pri slušanju toga djela - kod osnovaca, osobito kod učenika šestoga razreda, veći broj nego što bi bilo očekivano navodi da su doživjeli smirenost, dok je kod srednjoškolaca obratan 
trend (osobito kod učenika četvrtoga razreda). Razlike su uočljive i kod izazvane emocije ljutnje, uznemirenosti: tu emociju u većem broju od očekivanoga navode učenici drugoga razreda srednje škole, dok učenici svih ostalih razreda to navode u manjem broju nego što bi bilo očekivano. Tugu je doživio veći broj od očekivanoga broja učenika četvrtoga razreda srednje škole, dok je kod osnovaca manji broj učenika od očekivanoga doživio tugu, a frekvencija učenika drugoga razreda srednje škole koji navode da su doživjeli tugu odgovara teorijski očekivanim frekvencijama. Emociju je straha doživjelo manje učenika šestoga razreda nego što se očekivalo i više osmoga razreda nego što se očekivalo (opažene frekvencije srednjoškolaca odgovaraju očekivanima). Kako sudionici kao najčešće emocionalne reakcije navode tugu, smirenost i strah, provjereno je trima jednosmjernim analizama varijance postoji li statistički značajna razlika u intenzitetu tih emocija kod učenika različite dobi - neznačajni F-omjeri upućuju na to da ne postoje dobne razlike u intenzitetu triju najčešće doživljenih emocija.

Neznačajan hi-kvadrat upozorio je na to da se ne razlikuje čestina onih koji navode da im je ulomak (ne)poznat s obzirom na to koji razred pohađaju.

Hi-kvadrati kojima je provjereno razlikuju li se učenice od učenika te oni kojima je ulomak poznat od onih kojima je nepoznat po tome koje su emocije naveli kao reakciju na slušano djelo otkrivaju da su razlike statistički neznačajne, upozoravajući na to da se u tim skupinama u podjednakim omjerima navodi kako su učenici doživjeli šest emocionalnih reakcija pri slušanju toga ulomka.

Provjereno je postoje li spolne razlike, razlike s obzirom na poznatost toga ulomka u intenzitetu emocija koje su sudionici doživjeli pomoću triju t-testova za nezavisne uzorke. Pokazalo se da oni kojima je ulomak poznat $(M=3,93 ; S D=1,014)$ doživljavaju mnogo intenzivnije emocije $\left(\mathrm{t}_{302}=-2,77 ; \mathrm{p}=0,006\right)$ od onih kojima je ulomak nepoznat $(M=3,28 ; S D=1,305)$ - ovdje je vidljivo da učenici kojima je ulomak poznat navode da im je izazvao dosta intenzivnu emociju, dok je emocija onih kojima je ulomak nepoznat osrednjega intenziteta.

To djelo pokazalo se najmanje poznatim među svim prezentiranim ulomcima, zbog toga što navedeni ulomak iz hrvatske rock-opere Gubec-beg pripada nastavnom sadržaju koji se realizira tek na kraju završnoga razreda poučavanja Glazbene umjetnosti u gimnazijama. Zbog promjena u tempu, kao i zbog ekspresivnoga pjevanja Josipe Lisac, ali i zbog teksta koji je donio specifičan emocionalni kontekst, to je djelo izazvalo vrlo raznolike emocije kod učenika.

Spolne razlike pojavljuju se sporadično i uglavnom ih se vezuje uz poznate razlike u inhibiciji izražavanja emocija kod dječaka i inhibiciji izražavanja nepoželjnih emocija poput ljutnje kod djevojčica. 


\section{Zaključak}

Unatoč iznimnom zanimanju za istraživanja emocija u glazbi, tek rijetki glazbeni pedagozi upozoravaju na važnost toga fenomena u nastavi glazbe. Afektivni odgovor, emocionalni doživljaj učenika na slušano djelo, ima značajan utjecaj na motivaciju učenika i razvijanje interesa za glazbeno djelo. Pozitivno usmjereni subjektivni emocionalni odgovor učenika i emocionalni doživljaj utjecat će na spremnost za aktivno slušanje djela i spoznajne metodičke postupke koji će uslijediti, a sasvim će sigurno takav pristup utjecati i na konačno estetsko iskustvo.

Rezultati provedenoga istraživanja, u skladu s činjenicom da su učenici odabirali svih šest ponuđenih osnovnih emocija neovisno o dobi i spolu, upućuju na spremnost učenika da se u glazbenoj nastavi metodički putevi otvore i emocionalnoj sastavnici glazbenoga djela. Rezultati također upućuju na to da se slušanju može pristupiti, osim isključivo u smjeru analize glazbenoga djela, i kroz subjektivno emocionalno shvaćanje glazbe i glazbeni doživljaj. Kako je u pojedinim primjerima potvrđena povezanost između intenziteta doživljenih emocija kod učenika kojima je slušni ulomak bio poznat te da učenici koji navode da im je ulomak poznat doživljavaju intenzivniju emociju od onih kojima je ulomak nepoznat, tim su rezultatom potvrđena saznanja iz dosadašnjih istraživanja. ${ }^{43}$ Isto se tako ponovno osvijestila važnost i značaj glazbene nastave u osnovnoj i srednjoj školi u kojoj »učenici upoznavanjem i doživljavanjem glazbe različitih stilova i vrsta $\ll{ }^{44}$ sustavno stječu brojne glazbene kompetencije. Potvrđena je i potreba za aktivnim slušanjem, u kojem se glazba i glazbeno djelo tretira kao cilj umjetničke spoznaje, a za takav je način slušanja ključan višekratni postupak kojim se učenici opetovanim slušanjem upoznaju s glazbenim pojavnostima i pamte ih te kojim glazba na njih ostavlja umjetnički i emocionalni dojam. U konačnici se ponajviše ističe važnost učitelja, glazbenoga pedagoga, koji metodički kvalitetnim i angažiranim radom svakodnevno pronalazi načine da motivira učenike za slušanje, ali i u skladu s otvorenim kurikulom za nastavni predmet te osobnim preferencijama odabire atraktivan, umjetnički vrijedan repertoar, s kojim će se učenici moći i emocionalno povezati.

${ }^{43}$ Isto. T. ŠKOJO, Induciranje emocija glazbom s osvrtom na ulogu glazbene poduke, 101-114.

${ }^{44}$ Isto. MINISTARSTVO ZNANOSTI I OBRAZOVANJA, Odluka o donošenju kurikuluma za nastavni predmet Glazbene kulture za osnovne škole i Glazbene umjetnosti za gimnazije u Republici Hrvatskoj, 


\title{
THE EMOTIONAL ASPECT OF LISTENING TO MUSIC
}

\author{
Tihana ŠKOJO*
}

Summary: Despite the exceptional interest in studying emotions in music, only a few music pedagogues have warned of the importance of this phenomenon in teaching music. The paper analyzes the results of empirical research to determine the experienced emotions on listening to the following musical examples: C. Saint-Saëns: Carnival of Animals, Finale; I. Stravinsky: The Rite of Spring, Introduction; J. Williams: Schindler's List; F. Livadić: Nocturne in F-sharp minor; I. Malec: Lumina; and I. Krajač, K. Metikoš and M. Prohaska: Gubec-Beg, Jana's Madness.

The results of the research actualize the importance of students' emotional response to a musical work and contribute to the efforts of individual music pedagogues to emphasize the need for a comprehensive reception of a musical work that will include emotional dimension in addition to knowledge and understanding.

Keywords: emotions, listening, musical work, music repertoire, music pedagogue, music teaching, student.

\footnotetext{
* Asst. Prof. Tihana Škojo, Ph. D., Academy of Arts and Culture in Osijek, J. J. Strossmayer University
} of Osijek, Ulica Kralja Petra Svačića 1/F, 31000 Osijek, Croatia, tihana.skojo@aukos.hr 